\title{
A MINERAÇÃO DE DIAMANTES E A ADMINISTRAÇÃO GERAL DOS TERRENOS DIAMANTINOS: MINAS GERAIS, DÉCADAS DE 1830-1870'
}

\author{
Marcos Lobato Martins \\ Universidade Federal de Alfenas
}

\section{Resumo}

O artigo examina a atuação da Administração Geral dos Terrenos Diamantinos, órgão encarregado de regular e fiscalizar as lavras, registrar os terrenos diamantinos e administrar os direitos de lavra, no período compreendido entre os anos 1830 e 1870. Enfatizam-se as estratégias da repartição, bem como os conflitos e as negociações que envolveram os agentes que extraíam e comercializavam diamantes, especialmente nos municípios de Diamantina e Serro.

\section{Palavras-chave}

Mineração - Administração Geral dos Terrenos Diamantinos - regulação e fiscalização de lavras.

1 Agradeço à Fapemig pelo financiamento do projeto "O afã de diamantes e a letra da lei: negócios minerários, regulação, fiscalização e conflitos de interesses em Diamantina, 1832-1889". 


\title{
THE DIAMOND'S
}

MINING AND

THE GENERAL

ADMINISTRATION

OF DIAMOND

LANDS:

MINAS GERAIS, DECADES

OF 1830-1870

Contact

Rua Belo Horizonte, 71. Residencial Oliveira 37130-000 - Alfenas - Minas Gerais E-mail: lobatohistoria@hotmail.com

\section{Marcos Lobato Martins}

Universidade Federal de Alfenas

\begin{abstract}
The article examines the action of the General Administration of Diamond Lands, governmental department responsible to regulate and inspect the mines, register the diamond lands and administer the rights of mining, in the years 1830-1870. It emphasizes the strategies of the department, as well as the conflicts and negotiations with the diamond's miners and dealers, especially in Diamantina and Serro counties.
\end{abstract}

\section{Keywords}

Mining - General Administration of Diamond Lands - regulating and inspection of the mines. 
Desde o século XVIII, a mineração na região de Diamantina foi objeto de enorme atenção das autoridades. O contrabando, a evasão fiscal, a clandestinidade dos serviços de lavra, a corrupção das autoridades constituíram elementos importantes do cenário regional. ${ }^{2}$ Em muitas ocasiões, estiveram contrapostos os interesses do Estado e dos proprietários locais. Por outro lado, a assimetria de forças dos atores envolvidos na mineração também gerou conflitos pela posse dos terrenos diamantinos e a repartição do produto das lavras. Entre os estudiosos da mineração diamantífera, predomina a visão de que esses conflitos foram resolvidos mais pela violência do que pelo recurso a instituições (como os tribunais), fato que demonstraria as dificuldades que o Estado encontrou para impor-se na região. É o que afirma, enfaticamente, José Martins Catharino, referindo-se à legislação minerária:

Toda esta parafernália legislativa, que vem desde as Ordenações, para disciplinar querimas e querimônias, proprietarista exclusivamente, na Bahia, como em Minas - mais no passado que no presente, sempre esteve ao sabor dos mais poderosos - ter é poder. Na Bahia, p. ex., na época dos coronéis, dos quais Horácio Mattos foi pontífice, com corte na cidade de Lençóis (...), a lei efetiva era a que impunham, com força militar própria, constituída de jagunços. (...) No que tange à garimpagem, ao trabalho em garimpo, o direito consuetudinário, até hoje, embora menos, é dominante, manifestado e mantido à parte do "cascalho normativo formal"."

O objetivo deste artigo é compreender a complexa gama de conflitos e negociações que enredou os agentes envolvidos com a extração diamantífera, na região de Diamantina. Mais especificamente, investigar a atuação da Administração Geral dos Terrenos Diamantinos, órgão governamental encarregado de regular e fiscalizar os serviços de mineração, registrar os terrenos diamantinos e administrar os direitos de lavra.

O recorte cronológico abrange o período compreendido entre os anos 1830 e 1870, período para a qual são escassos os estudos sobre a "economia do diamante". Trata-se de época de afirmação dos pilares do Estado monárquico e, no plano da legislação minerária, da vigência do regime dominial. ${ }^{4}$ O ano de 1832 assinalou o declínio definitivo da Real Extração, reduzida a

\footnotetext{
2 FURTADO, Júnia Ferreira. O Livro da Capa Verde: o regimento diamantino de 1771 e a vida no Distrito Diamantino no período da Real Extração. São Paulo: Annablume, 1996.

3 CATHARINO, José Martins. Garimpo, garimpeiro, garimpagem. Rio de Janeiro: Philobiblion; Salvador: Fundação Econômica Miguel Calmon, 1986, p. 217-218.

4 Ver MATTOS, Ilmar Rohloff de. O tempo de Saquarema. São Paulo: Hucitec, 1987.
} 
um único feitor e pequena tropa de cativos. ${ }^{5}$ Já os anos 1870, marco final do recorte, assinalam o início de forte e longa crise regional da mineração, decorrente da queda internacional dos preços do diamante por causa da produção sul-africana. Crise que acelerou a concentração das terras minerais, estimulou investimentos industriais e comerciais das elites diamantinenses e acendeu debates na imprensa local sobre o futuro do nordeste mineiro, tudo isso no contexto de decadência do escravismo e do regime monárquico. ${ }^{6}$

As fontes utilizadas neste artigo são os registros da Administração Geral dos Terrenos Diamantinos, ${ }^{7}$ almanaques de época, e o relato de viagem do naturalista e embaixador suíço Johann Jakob von Tschudi, que esteve em Diamantina no final da década de 1850.

\section{A legislação minerária no período imperial}

A Constituição de 1824 adotou o regime dominial, pelo qual os minérios eram considerados propriedade do Estado. Esse regime é aperfeiçoamento do regime realengo que vigorara na colônia, ${ }^{8}$ tendo sido impelido pela dupla necessidade de racionalizar e fomentar a atividade mineradora. Nesse modelo, é "o Estado, representante dos interesses nacionais e o titular das riquezas minerais, que pode explorá-las diretamente, independente de concessão, ou conceder a sua exploração a particulares". Ao Estado competiam as funções de controle e fiscalização da prospecção e do aproveitamento das jazidas. Ao concessionário impunha-se explorar efetivamente os recursos, em prol de um "interesse público", e repassar aos cofres públicos os pagamentos de impostos cobrados sobre a atividade minerária. Quanto ao

\footnotetext{
5 SANTOS, Joaquim Felício dos. Memórias do Distrito Diamantino. 5. ed. Petrópolis, RJ: Vozes; Brasília: INL, 1978, p. 391

6 Para maiores detalhes, consultar MARTINS, Marcos Lobato. A crise dos negócios do diamante e as respostas dos homens de fortuna no Alto Jequitinhonha, décadas de 1870-1890. Estudos Econômicos. São Paulo, v. 38, n. 3, 2008, p. 611-638.

7 Estes documentos integram o Fundo dos Terrenos Diamantinos (TD) do Arquivo Público Mineiro (APM).

8 Léo Ferreira Leoncy explica que, "no modelo realengo, os recursos minerais integram-se na categoria dos direitos reais, isto é, nos direitos do soberano. Os bens minerais constituíam no bloco apropriado pelo particular uma exceção em favor do rei (...). [Assim] Sendo o soberano o proprietário das minas e jazidas, delas podia dispor livremente, concedendo permissão de lavra a quem lhe aprouvesse". LEONCY, Léo Ferreira. O regime jurídico da mineração no Brasil. Belém: NAEA/UFPA, 1997, p. 4-5.

9 VASCONCELOS, José Matos de. Direito administrativo. Rio de Janeiro: Imprensa Nacional, 1936, p. 246.
} 
proprietário fundiário, dono do terreno onde havia jazidas, a legislação garantia o direito à preferência para exploração e lavra do subsolo, bem como o direito à indenização por danos eventualmente causados pelos serviços de lavra conduzidos por terceiro.

O regime dominial, todavia, não conseguiu eliminar as disputas entre mineradores, garimpeiros e proprietários de terras. Interpretações controversas da Constituição de 1824 criaram indefinição sobre a separação da propriedade do solo e do direito de explorar as riquezas minerais..$^{10}$ Essa indefinição opôs mineradores e donos de terras." ${ }^{11}$ Os grandes mineradores tenderam a recusar o pagamento de percentual do resultado da "apuração" para os donos dos terrenos onde ficavam as lavras. ${ }^{12}$

Na década de 1830, a opção do governo imperial foi a de colocar nas mãos das províncias a responsabilidade pelo controle das lavras e dos mineradores. Para os diamantes, restou a obrigação de lapidar as pedras no Rio de Janeiro, nas dependências da "Fábrica de Lapidação" do Tesouro Nacional. O resultado prático dessa opção foi a progressiva alteração do tom da legislação minerária nas décadas seguintes. A ênfase deixou de ser a repressão aos descaminhos do ouro e do diamante, como no período colonial, para recair sobre a produção mineral, considerada fator importante para o desenvolvimento do país. ${ }^{13}$

\footnotetext{
${ }^{10}$ Grosso modo, a controvérsia girou em torno do artigo $179, \S 22$, que garantia a propriedade em toda sua plenitude, sem fazer qualquer menção a solo ou a subsolo. Assim, houve quem defendesse a posição de que a propriedade da terra abrangia também a propriedade dos recursos minerais nela existentes. Esse entendimento conflitava, porém, com a lei de 20 de outubro de 1823 que determinara a vigência da legislação do Reino até que fosse expressamente revogada, com a diferença de que as minas e quaisquer outras riquezas do subsolo passaram a constituir domínio da nação.

${ }^{11}$ Um relatório enviado por Roberto Alves Ferreira Taioba, de 13 de setembro de 1856, indicava ao governo que, na busca de melhorar a atuação da Administração Geral dos Terrenos Diamantinos, seria preciso esclarecer as atribuições da justiça fazendária e os limites dos direitos de mineradores e donos do solo, confusos no artigo 39 do decreto de 17 de agosto de 1846 (APM. TD-04, fls. 8v-9).

${ }^{12} \mathrm{O}$ termo "apuração" nomeia a etapa final do processo tradicional de mineração, quando os cascalhos são lavados com o uso de peneiras e bateias, de modo a se proceder cuidadosamente à separação do ouro e dos diamantes. É então que se conhece o resultado bruto do serviço de lavra.

13 Sobre as preocupações setecentistas com os descaminhos do diamante, ver FERREIRA, Rodrigo de Almeida. $O$ descaminho de diamantes - relações de poder e sociabilidade na demarcação diamantina no período dos contratos (1740-1771). Belo Horizonte: Fumarc; São Paulo: Letra \& Voz, 2009. E FURTADO, Júnia Ferreira. O Livro da Capa Verde: o regimento diamantino de 1771 e a vida no Distrito Diamantino no período da Real Extração. São Paulo: Annablume, 1996.
} 
A peça-chave da engrenagem do controle e fiscalização da mineração diamantífera foi a Inspetoria da Administração e Extração Diamantina, criada pelo decreto de 24 de setembro de 1845, que extinguiu a antiga Junta Diamantina. ${ }^{14}$ A esse órgão, que se tornou mais conhecido como Administração Geral dos Terrenos Diamantinos, competia fazer o registro das áreas das jazidas, das concessões e autorizações para lavra, evitar exploração indevida de terrenos diamantíferos e prestar contas à Tesouraria da Província da movimentação de exploração e arrecadação. Instalada na cidade de Diamantina, a repartição era subordinada à Tesouraria da Fazenda da Província. O órgão era chefiado por um inspetor geral e um procurador fiscal. Conforme o viajante Johann Jakob von Tschudi, que visitou Diamantina em 1858, o minerador tinha de obter nessa repartição uma permissão anual ao custo de dois mil-réis, que também o autorizava a trabalhar com escravos. ${ }^{15}$

A informação de Tschudi não é inteiramente correta. As taxas cobradas pela Administração Geral dos Terrenos Diamantinos variaram bastante no período 1832-1895. Disso dá mostras o ofício do inspetor geral para o deputado geral Teodomiro Alves Pereira, datado de 24 de janeiro de $1868 .{ }^{16}$ Nele são apontadas as alterações sofridas pelo imposto anual cobrado sobre os lotes diamantinos. O decreto de 6 de setembro de 1854 fixara o imposto em um mil réis por braça quadrada de terreno explorado, e cinco mil réis para terrenos virgens. Mas a lei do orçamento de 26 de setembro de 1864 aumentou os valores: cinco mil réis para terrenos explorados e 10 mil réis para terrenos virgens. ${ }^{17}$

Um rápido parêntese. Para que se possa aquilatar o significado das cifras que são citadas nesse artigo, apresentam-se alguns preços que vigoraram em Diamantina, entre 1858 e 1861: o jornal diário de um pedreiro, de um mil e duzentos réis a dois mil réis; um cavalo, cerca de 25 mil réis; uma porca, cerca de seis mil réis; uma casa coberta de telhas, aproximadamente 150 mil réis; uma boa chácara nas proximidades da cidade, 500 mil réis; frango, cerca de 200 réis; a garrafa de leite, 80 réis. $^{18}$

${ }^{14}$ SANTOS, Joaquim Felício dos Santos. Memórias do Distrito Diamantino, 1978, op. cit., p. 404.

${ }^{15}$ TSCHUDI, Johann Jakob von. Viagens através da América do Sul. Trad. Friedrich E. Renger. Belo Horizonte: Fundação João Pinheiro, 2006, v. 2, p. 127.

${ }_{16}$ APM. TD-04, fls. 49v-50v.

${ }^{17}$ Havia também a despesa dos arrendatários correspondente ao pagamento do prático responsável pela medição e demarcação dos lotes diamantinos (Relatório de Roberto Alves Taioba, substituto do inspetor geral, 13 de setembro de 1856. APM. TD-04, fls. 8v-9).

${ }^{18}$ Uma lista de preços de bens e serviços em Diamantina no período em tela pode ser encontrada em SOUZA, José Moreira de. Cidade: momentos e processos. Serro e Diamantina na formação do norte mineiro no século XIX. São Paulo: Marco Zero, 1993. 
Os termos de contrato de arrendamento de lotes diamantinos fixavam as relações entre os mineradores e a Administração Geral dos Terrenos Diamantinos, como mostra o documento transcrito abaixo, que solicita a revisão da medição de um lote mineral, para determinar sua área útil:

Aos doze dias do mês de abril de 1869 nesta cidade do Serro, em casa do Advogado Antônio Caetano de Ávila e Silva, Delegado dos Terrenos Diamantinos deste município, onde eu Agente do Procurador Fiscal abaixo declarado fui vindo e sendo aí foi apresentada pelo Prático Tristão Cardozo Neves a medição do lote de terreno diamantino no Córrego do Amolar, arrematado em hasta pública em 1867, por José Pedro Lessa e Francisco Cornélio Ribeiro, como consta de uma petição que apresentaram, a qual fica arquivada; e como requereram nesta data que se procedesse a medição do referido lote assim ordenou o Delegado (...). Somando toda esta medição 24 mil braças quadradas, das quais abstraídas as inúteis, ficam líquidas 14 mil braças quadradas, que a preço fixo de um real por cada braça por ter sido a arrematação feita antes da nova lei, importa em 14\$000 que os arrendatários ficam obrigados a pagarem na Coletoria desta Cidade anualmente enquanto não rescindirem do contrato ou o poder competente não mandar o contrário. (...) E de tudo para constar, mandou o Delegado lavrar o presente termo em que se assina com os arrendatários depois de lido por mim. Joaquim Ferreira de Araújo. Agente do Procurador Fiscal. ${ }^{19}$

O documento ilustra os procedimentos de gerenciamento da mineração empregados pela Administração Diamantina. Primeiro, fazia-se a medição dos lotes. Em seguida, os lotes demarcados eram levados a hasta pública. $\mathrm{O}(\mathrm{s})$ arrematante(s) registrava (m) os contratos na Administração, o que podia demorar alguns anos. Depois, pagavam os impostos na Coletoria provincial. Caso cessasse a exploração dos lotes ou ocorresse transferência ou venda de direito minerário, a Administração teria que ser imediatamente informada.

Convém assinalar que a legislação minerária do período insistiu em penalizar os faiscadores. Estes continuaram marginalizados, tratados com desconfiança e hostilidade. Mal vistos tanto pelos grandes mineradores quanto pelas autoridades, os faiscadores foram discriminados pelo regulamento de 17 de agosto de 1846. O artigo 25 determinava que, em cada área de exploração diamantífera, a Administração Diamantina demarcaria um distrito específico dentro do qual os faiscadores poderiam trabalhar livremente. O artigo 29 vedava aos faiscadores a faculdade de minerar em todos os lugares devolutos.

${ }^{19}$ APM. TD-08, fls. 135v-136. 
Mais do que afinado com as posições liberais em voga, o regime de livre extração parecia estimular a atividade, justamente pela relativa modicidade das obrigações sobre quem extraía e comercializava pedras preciosas. A propósito, vale lembrar o comentário de Tschudi, feito logo após sua visita à rica lavra de São João do Barro:

\begin{abstract}
Atualmente, qualquer um que tiver tempo, vontade e dinheiro pode dedicar-se a essa tarefa [extração de diamantes]. O fisco desfruta vantagens modestas, visto que cada proprietário de uma lavra de diamantes (serviço) paga, anualmente, apenas um real por braça de terreno por ele trabalhado. Além disso, para cada diamante que sai da província cobra-se um imposto de exportação, correspondente a meio por cento de seu valor. ${ }^{20}$
\end{abstract}

A julgar pela observação de Joaquim Felício dos Santos, a legislação imperial para o setor teria causado onda de otimismo, ensejando a multiplicação das descobertas. Citando relatório de 1840 da Junta Diamantina ao presidente da Província, o grande tribuno do Tijuco escreveu:

Cumpre observar que além da numerosa população, que tira sua subsistência imediatamente da mineração, um número muito mais considerável a obtém indiretamente. Sem falar na classe do comércio, que põe em giro neste país avultada soma de capitais, a agricultura não tem outro fiador, que não seja a mineração; e o município da Diamantina consome, além de seus próprios produtos agrícolas, o excesso de produção que superabunda no município da cidade do Serro, habitado por mais de 100 mil almas, e consideráveis exportações de outros municípios limítrofes, como os de Formigas, Curvelo e Minas Novas. ${ }^{21}$

\title{
Os serviços de lavra e os negócios de diamante em meados do século XIX
}

Na região, as atividades de lavra abarcavam dois setores distintos, embora articulados e mesmo interdependentes: a grande mineração e o garimpo. Foi justamente a grande mineração que os viajantes estrangeiros conheceram, desde Eschwege, Saint-Hilaire até Richard Burton, passando por

${ }^{20}$ TSCHUDI, Johann Jakob von. Viagens através da América do Sul, 2006, op. cit., v. 2, p. 96-97.

${ }^{21}$ SANTOS, Joaquim Felício dos. Memórias do Distrito Diamantino, 1978, op. cit., p. 394-395. 
Johann Jakob von Tschudi, que será nosso guia na reconstituição da economia do diamante na década de $1850 .{ }^{22}$

O que Tschudi conheceu da mineração de diamantes deve-se a sua visita à lavra de São João do Barro, em 1858. Ele esteve lá na companhia de Serafim José de Menezes (futuro barão de Araçuaí, o homem mais rico de Diamantina), Francisco José de Almeida e Silva (grande "diamantário" e proprietário de lavras no ribeirão do Inferno) e Rodrigo de Sousa Reis (também "diamantário" e dono da lavra do Barro). ${ }^{23} \mathrm{O}$ viajante encontrou uma sociedade organizada para explorar 21.770 braças de terra, que tocava uma lavra que fornecia pedras muito boas, da mais pura água, e com muito pouco refugo. ${ }^{24}$ Esta lavra era um buraco enorme, com 60 pés de profundidade. Nela estavam ocupados 120 negros. Os donos da lavra pagavam, por semana, 4 mil-réis por escravo alugado. Além disso, eram obrigados a fornecer-lhes alimentação e, em caso de doença, assistência médica aos cativos, ao passo que os donos dos escravos davam apenas as roupas. ${ }^{25}$ Durante as poucas horas em que esteve na lavra do Barro, o viajante presenciou a extração de cerca de 30 quilates de diamante. Segundo relato de seus acompanhantes, na época da lavagem, durante os meses da chuva, eram achados diariamente entre 35 e 70 quilates, que perfaziam, em média, 100, 200, até 220 diamantes; desse modo, durante toda a estação, a lavra fornecia, no máximo, quatro mil quilates de diamantes. ${ }^{26}$

Tschudi foi informado de que, nas grandes lavras da região, o ouro era subproduto. Subproduto bem-vindo porque pagava pelo menos a alimentação dos escravos empregados. ${ }^{27}$ Ainda conforme o viajante, os custos de produção das grandes lavras estavam subindo. No início dos anos 1850, a produção de uma oitava ${ }^{28}$ de diamante custava a média de 200 mil-réis. Mas, em 1858,

${ }^{22}$ ESCHWEGE, Wilhelm L. von. Pluto Brasiliensis. Trad. Domício de Figueiredo Murta. Belo Horizonte: Itatiaia; São Paulo: Edusp, 1979. SAINT-HILAIRE, Auguste de. Viagem pelo distrito dos diamantes e litoral do Brasil. Trad. Leonam de Azeredo Pena. Belo Horizonte: Itatiaia; São Paulo: Edusp, 1974. BURTON, Richard F. Viagem de canoa de Sabará ao oceano Atlântico. Trad. David Jardim Junior. Belo Horizonte: Itatiaia; São Paulo: Edusp, 1977.

23 "Diamantário" é o nome regional para os comerciantes de diamantes, que compram diretamente dos mineradores as partidas de gemas e as revendem para as praças do Rio de Janeiro e da Europa.

${ }^{24}$ TSCHUDI, Johann Jakob von. Viagens através da América do Sul, 2006, v. 2, op. cit., p. 131.

${ }^{25}$ TSCHUDI, Johann Jakob von. Viagens através da América do Sul, 2006, v. 2, op. cit., p. 132.

${ }^{26}$ TSCHUDI, Johann Jakob von. Viagens através da América do Sul, 2006, v. 2, op. cit., p. 128-131.

${ }^{27}$ TSCHUDI, Johann Jakob von. Viagens através da América do Sul, 2006, v. 2, op. cit., p. 155.

${ }^{28}$ A oitava representa 17,5 quilates de diamante; o quilate, por sua vez, é equivalente a $200 \mathrm{mg}$ de pedras preciosas. 
o custo estaria, comparativamente, cerca de $10 \%$ mais alto. ${ }^{29}$ Dois fatores concorreram para a elevação do custo de produção das grandes lavras: o encarecimento da mão-de-obra escrava e a maior dificuldade de exploração do diamante de "massa" que, então, era o tipo mais comum das novas descobertas. ${ }^{30}$

Por isso, o viajante deu crédito à queixa dos grandes mineradores a propósito da rentabilidade baixa dos grandes serviços de lavra. Nas palavras de Tschudi:

Os donos da lavra de São João, assim como a maioria dos proprietários de lavras, não consideram que o negócio de diamantes seja muito lucrativo. O custo da operação é muito alto. (...) Os produtores têm que se contentar com um lucro pequeno enquanto veem os comerciantes, que são os intermediários do produto, se enriquecerem. ${ }^{31}$

Sobre a produção de garimpeiros, Tschudi limitou-se a dizer que eles eram pessoas pobres que procuravam diamantes por meios simples e, em geral, apenas com a ajuda de seus familiares e amigos. ${ }^{32}$ Sua descrição do garimpeiro é carregada de indisfarçável preconceito:

Em geral, os garimpeiros levam uma vida muito pobre e trabalham bastante para obter uma produção bem pequena. Às vezes, um ou outro tem sorte e encontra uma pedra grande, que compensa plenamente os esforços de muitos anos. Esses casos, porém, são raros. Durante o tempo de paralisação do garimpo, vivem de forma miserável junto com os seus.

Na verdade, as turmas de garimpeiros atuaram em toda região da antiga Demarcação Diamantina, mobilizando milhares de homens em trabalhos manuais pesados e penosos. Por um lado, os garimpeiros foram historicamente responsáveis pelos maiores achados de diamante. Por outro lado, a produção dos garimpeiros, embora dispersa e fragmentada, sempre respondeu por expressiva parcela do volume total dos diamantes extraídos na região. ${ }^{33}$

Para enfrentar as obrigações impostas pela legislação minerária e contornar as dificuldades de acesso a lotes de terras minerais, os garimpeiros

\footnotetext{
${ }^{29}$ TSCHUDI, Johann Jakob von. Viagens através da América do Sul, 2006, v. 2, op. cit., p. 134.

${ }^{30} \mathrm{Na}$ página 134 de seu relato, Tschudi informa que o negro escravo custava, em média, 1:200\$000 rs na região de Diamantina. Já a expressão diamante de "massa" indica os depósitos de gemas encontrados longe dos cursos d'água, em morros que precisavam ser desmontados com água para se alcançar o cascalho diamantífero.

31 TSCHUDI, Johann Jakob von. Viagens através da América do Sul, 2006, v. 2, op. cit., p. 132.

32 TSCHUDI, Johann Jakob von. Viagens através da América do Sul, 2006, v. 2, op. cit., p. 127.

33 Conforme MARTINS, Marcos Lobato. Identidades sociais e ação coletiva: o caso dos garimpeiros da microrregião de Diamantina. Dissertação de mestrado, Sociologia, FAFICH, UFMG, 1997.
} 
frequentemente constituíram sociedades. Associações marcadamente informais, que operaram ancoradas nos valores, técnicas e práticas tradicionais da mineração regional, resultantes de acordos verbais entre amigos e familiares, poucas vezes registradas nos órgãos oficiais. Exemplo de rara associação de garimpeiros formalizada diante do Estado aparece no documento abaixo, datado de $1^{\circ}$ de março de 1869, referente à exploração do córrego do Bernardino, no Serro:

Sociedade que entre si fazem Paulo Fernandes Leão, Pedro Barreto Lima, Torquato Pinheiro das Neves, Antônio Raimundo da Costa e Marcelino José de Azevedo. Neste ato concordaram (...) de formarem entre si uma sociedade pela maneira seguinte, Que tendo os três primeiros seis mil braças de terreno diamantino no Córrego do Bernardino, e os dois últimos outro lote no mesmo córrego (...), cuja sociedade é fundada nos seguintes quesitos: $1^{\circ}$ Q Que os três primeiros sócios não poderão empregar na lavra mais do o número de 6 trabalhadores para cada um dos 3 sócios excetuando suas pessoas, e os 2 segundos sócios Antônio Raimundo e Marcelino poderão empregar nove trabalhadores cada um além de suas pessoas; $2^{\circ}$ ) Que observarão restritivamente a cláusula de que nenhum deles sócios poderão facultar a lavra a agregado algum; $3^{\circ}$ ) Que respeitarão os serviços uns dos outros, não estorvando-os de forma alguma; $4^{\circ}$ ) Que qualquer um dos sócios que não observar este contrato religiosamente pagará de multa a quantia de $100 \$ 000$ que será repartida entre os outros sócios, cuja multa será verificada todas as vezes que houver infração do presente contrato, o que tudo foi aceito pelos sócios; 5) Que qualquer um dos sócios que quiser vender o direito que tem na lavra, o poderá fazer, dando preferência aos outros sócios, e no caso de que estes não queiram comprar, poderá vender a qualquer estranho de combinação com os outros sócios. E de como assim se concordaram, e se sujeitaram mandar o Delegado lavrar o presente termo. ${ }^{34}$

Os numerosos faiscadores, indivíduos que trabalhavam isolados na cata de diamantes, exploravam locais anteriormente minerados ou terras distantes e de difícil acesso. Muitas vezes, "capangueiros", comerciantes e donos de lavras ajudavam os faiscadores em suas despesas, em troca de participação na produção obtida e da preferência na compra dos diamantes. Dessa forma, como no caso das turmas de garimpeiros, também havia relações de complementaridade entre os faiscadores e os maiores agentes dos negócios de diamantes. ${ }^{35}$

34 APM. TD-08, fls. $125 \mathrm{v}-126 \mathrm{v}$.

${ }^{35}$ Para discussão mais detalhada das interações entre grandes mineradores e faiscadores, ver CATHARINO, José Martins. Garimpo, garimpeiro, garimpagem. Rio de Janeiro: Philobiblion; Salvador: Fundação Econômica Miguel Calmon, 1986. SCLIAR, Cláudio. Geopolítica das minas do Brasil. Rio de Janeiro: Revan, 1996. MARTINS, Marcos Lobato. Identidades sociais e ação coletiva: o caso dos garimpeiros da microrregião de Diamantina. Dissertação de mestrado, Sociologia, FAFICH, UFMG, 1997. 
Tschudi notou que o "negócio de diamantes" era mais do que uma atividade econômica. Em Diamantina, havia se convertido numa "mania dos janotas", verdadeiro emblema de masculinidade, maturidade e distinção social. É o que se depreende do trecho escrito pelo viajante:

Houve um tempo em que todo mundo em Diamantina fazia negócio com diamantes (...). Hoje essa prática decresceu bastante (...). Contudo, ainda hoje é raro encontrar um jovem de boa família que não leve uma porção de diamantes em sua capanga, a fim de negociá-los na primeira oportunidade. O comércio de diamantes é uma paixão entre os jovens abastados de Diamantina. ${ }^{36}$

Em 1858, os preços praticados no comércio de diamante na praça da cidade eram atrativos. Os diamantes puros de uma oitava vendiam-se por três contos de réis. As pedras de duas oitavas custavam sete ou oito contos de réis. Já uma oitava de "mercadoria boa" vendia-se por 500 mil réis. ${ }^{37}$ Por isso mesmo, a condição de "diamantário" era bastante cobiçada, ainda que somente poucos conseguissem alcançá-la. A riqueza gerada pelo diamante forjou hábitos entre as camadas abastadas da cidade, a exemplo das frequentes viagens para a Corte. Conforme Tschudi, "quase todos os grandes comerciantes [de Diamantina] visitam a capital do império pelo menos uma vez por ano para fazer compras. Retornam com quantias de 200, 300, até 700 contos de réis, fruto da venda de diamantes". ${ }^{38}$ Sobre as práticas dos negociantes de diamantes, o relato de Tschudi informa:

Em Diamantina, os grandes comerciantes de diamante têm seus compradores, que viajam por todo o distrito e vão até Grão-Mogol e Sincorá latual Coromandel, no Triângulo Mineirol para comprar diamantes de pequenos proprietários de lavras, garimpeiros e negros. São conhecidos como capangueiros (...). Compram as pedras por conta e risco ou com um adiantamento dos grandes comerciantes e atacadistas. Em geral, esse negócio é muito lucrativo, porque eles compram boas mercadorias por preços relativamente baixos. Contudo, às vezes acontece de o preço baixar depois de uma viagem de alguns meses e, assim, eles perdem parte do capital aplicado. ${ }^{39}$

A passagem acima do relato de Tschudi é esclarecedora: em torno dos diamantários, estendiam-se imensas e capilares redes de "capangueiros", que

\footnotetext{
36 TSCHUDI, Johann Jakob von. Viagens através da América do Sul, 2006, v. 2, op. cit., p. 154.

37 TSCHUDI, Johann Jakob von. Viagens através da América do Sul, 2006, v. 2, op. cit., p. 152.

38 TSCHUDI, Johann Jakob von. Viagens através da América do Sul, 2006, v. 2, op. cit., p. 103.

39 TSCHUDI, Johann Jakob von. Viagens através da América do Sul, 2006, v. 2, op. cit., p. 154.
} 
vasculhavam as terras diamantinas mineiras e até baianas, no afã de adquirir boas pedras. Redes assentadas em relações pessoais, nas quais a confiança e a lealdade recíprocas eram valores centrais, e os lucros e os riscos eram repartidos de maneira assimétrica. Dessa forma, os negócios de diamante eram fortemente hierarquizados numa ponta como noutra, na extração e na comercialização. ${ }^{40}$

Apesar das estatísticas sobre a produção e comercialização de diamantes serem pouco confiáveis, em razão da tradicional clandestinidade de boa parcela das operações, vale apresentar os números compilados por Tschudi. Eles devem ser lidos muito mais como indicadores do vulto da atividade e de seu dinamismo. As tabelas seguintes trazem os dados:

\section{Tabela 1 - Quantidade e valor dos diamantes exportados pelo Rio de Janeiro (1857-1863)}

\begin{tabular}{|c|c|c|}
\hline Período & Oitavas & Valor (mil réis) \\
\hline $1857-58$ & 3.162 & $948: 600$ \\
\hline $1858-59$ & 5.021 & $1.506: 450$ \\
\hline $1859-60$ & 5.119 & $1.535: 700$ \\
\hline $1860-61$ & 5.863 & $2.506: 320$ \\
\hline $1861-62$ & 5.756 & $2.878: 198$ \\
\hline $1862-63$ & 6.970 & $2.468: 725$ \\
\hline
\end{tabular}

Fonte: TSCHUDI, 2006, p. 145-146.

\section{Tabela 2 - Receita do Estado nos distritos diamantinos}

\begin{tabular}{|c|c|}
\hline Período & Receita (réis) \\
\hline $1856-57$ & $41: 945 \$ 000$ \\
\hline $1857-58$ & $53: 084 \$ 000$ \\
\hline $1858-59$ & $58: 300 \$ 000$ \\
\hline $1859-60$ & $51: 432 \$ 000$ \\
\hline $1860-61$ & $37: 523 \$ 000$ \\
\hline $1861-62$ & $42: 516 \$ 000$ \\
\hline
\end{tabular}

Fonte: TSCHUDI, 2006, p. 145-146.

\footnotetext{
${ }^{40}$ MARTINS, Marcos Lobato. Os negócios do diamante e os homens de fortuna na praça de Diamantina, MG: 1870-1930. Tese de doutorado, História, FFLCH, USP, 2004.
} 
As cifras da tabela 1 mostram o estado de aquecimento da mineração diamantífera na região de Diamantina, que era a principal origem das pedras exportadas pelo porto do Rio de Janeiro. Os números da tabela 2, por sua vez, demonstram que, a despeito da enorme evasão fiscal que historicamente marca a exploração de diamantes no Brasil, a economia do diamante gerava rendas anuais avultadas para o Estado brasileiro. ${ }^{41}$

Conforme a documentação da Administração Geral dos Terrenos Diamantinos, na região do Serro, no período 1865-69, havia o registro de 174 termos de contrato de arrendamento de lotes. Alguns dos principais mineradores do município estão listados no anexo $1{ }^{42}$ As principais áreas de mineração eram: Rio do Peixe, Capivari, São Gonçalo e Pedra Redonda. As sociedades de mineradores e garimpeiros ocorriam com frequência, assim como era comum uma mesma pessoa ser titular de dois ou mais arrendamentos de lotes. Entretanto, raríssimas eram as concessões em nome de mulheres. No caso do Serro, dos 174 registros do período 1865-1869, encontra-se apenas uma mulher: dona Francisca Tereza d'Aguiar Souza, que possuía arrendamento no córrego de São Gonçalo. ${ }^{43}$

Bem mais animada era a mineração de diamantes no município de Diamantina. No período 1861-67, havia 2.447 matrículas de termos de arrendamento de lavra, sendo que os terrenos minerais variavam de 6.000 a 100 mil braças quadradas. ${ }^{44}$ Joaquim Felício dos Santos asseverava: "Durante o tempo das concessões, talvez se tirassem mais diamantes que a Extração

${ }^{41}$ A inflexão para baixo da renda do Estado nos dois últimos períodos da tabela 2 pode ser explicada, pelo menos em parte, pelo comportamento do preço médio da oitava no Rio de Janeiro. Mantendo-se estável em $300 \$ 000$ ao longo de quase toda década de 1850, o preço da oitava subitamente subiu para 427\$000, em 1860-61, e depois para 500\$000, em 1861-62, aumentos que devem ter estimulado o descaminho das pedras, de forma a engordar ainda mais os lucros dos comerciantes. Ver TSCHUDI, Johann Jakob von. Viagens através da América do Sul, 2006, v. 2, op. cit., p. 145-146.

${ }^{42} \mathrm{O}$ critério utilizado para classificar os mineradores foi o tamanho dos lotes, refletido na cifra de impostos anuais pagos. Em 1868, cada braça quadrada de terra mineral era taxada em cinco réis. Assim, os pequenos mineradores são aqueles que possuíam lotes que pagavam menos de $10 \$ 000$ (lotes de aproximadamente 29 mil metros quadrados ou três hectares); os médios mineradores são aqueles que possuíam lotes taxados entre $10 \$ 000$ e $20 \$ 000$ (área entre cinco e 10 ha); os grandes mineradores eram os que possuíam lotes que pagavam mais de $20 \$ 000$ anuais (área acima de 10 ha). ${ }^{43}$ APM. TD-08.

${ }^{44}$ APM. TD-06. Este dado do número de matrículas de terrenos minerais possibilita fazer estimativa dos trabalhadores diretamente envolvidos nos serviços de lavra. Conforme depoimentos de antigos garimpeiros, os garimpos manuais do início do século XX empregavam não menos do que oito ou dez pessoas. Como as técnicas eram as mesmas do século XIX, pode-se, portanto, calcular que o garimpo não empregava, nos anos 1860, menos que 19,5 mil pessoas. 
no espaço de setenta anos de sua existência". ${ }^{45}$ Felício dos Santos afirmava ainda: "não existe nesta demarcação córrego algum cujo leito esteja por se lavrar, e uma grande parte da mineração atual consiste em aproveitaremse os resíduos deixados pelos antigos contratadores e administrações, que minerando em grande, deixaram restingas ainda virgens". ${ }^{46}$ Conforme sua avaliação, nos anos 1860, o produto anual em impostos de arrendamento das lavras alcançava a cifra de 16 contos de réis. ${ }^{47}$

A partir dos registros da Administração Diamantina, as principais áreas de mineração nos anos 1860-1870 eram: rio Pardo Pequeno, Caldeirões, Jequitinhonha, córrego do Quilombo, Bambá, Serrinha, Datas, riacho das Varas, rio das Pedras e Caetemirim. A localidade de Mendanha, por exemplo, era um dos principais centros de mineração da região. Ali, o Almanak Administrativo, Civil e Industrial da Província de Minas Gerais do ano de 1869 (p. 203) anotou os nomes dos principais envolvidos com a mineração e o beneficiamento de produtos das lavras:

- mineradores: Antônio de Aguiar Pinto Coelho, capitão Ezequiel Neto Carneiro Leão, Francisco Gomes Tibães, capitão José Floriano Quirino, dona Maria Madalena dos Santos e Modesto Ribeiro de Almeida;

- capangueiros: Anselmo Pereira de Andrade, Joaquim Antônio de Oliveira e Joaquim Vieira Couto;

- ourives: Antônio José Ferreira, José Cândido de Figueiredo e Prudêncio Pereira de Andrade.

A partir dos cerca de 750 registros de lotes arrendados e dos arrendatários no município de Diamantina, constantes num livro da Fazenda Pública relativo ao período 1875-1890, tomou-se uma amostra aleatória de 252 nomes. ${ }^{48}$ Nessa amostra, pode-se verificar algo a respeito da distribuição dos tipos de lotes e do número de concessões por titulares de direitos minerários. As informações estão contidas nas tabelas seguintes:

Para depoimentos de antigos garimpeiros, ver MARTINS, Marcos Lobato. Identidades sociais $e$ ação coletiva..., 1997, op. cit., cap. 2.

45 SANTOS, Joaquim Felício dos. Memórias do Distrito Diamantino, 1978, op. cit., p. 403.

46 SANTOS, Joaquim Felício dos. Memórias do Distrito Diamantino, 1978, op. cit., p. 396.

47 SANTOS, Joaquim Felício dos. Memórias do Distrito Diamantino, 1978, op. cit., p. 392.

${ }^{48}$ APM. FP-107, fls. 91-125. Chama-se atenção para o fato de que o documento da Fazenda Pública possui número bem menor de registros de lotes arrendados no município de Diamantina do que os existentes nos livros da Administração Geral dos Terrenos Diamantinos. Uma explicação pode ser a seguinte: ele registra apenas os termos de contratos renovados no período. 
Tabela 3 - Tipos dos lotes arrendados no município de Diamantina (1875-1890)

\begin{tabular}{|c|c|c|}
\hline Tamanho dos terrenos diamantinos & N. de ocorrências & \% do total da amostra \\
\hline Pequeno & 213 & 59,5 \\
\hline Médio & 86 & 24,0 \\
\hline Grande & 59 & 16,5 \\
\hline
\end{tabular}

Fonte: APM. FP-107, fls. 91-125.

Tabela 4 - Distribuição do número de concessões por titular no município de Diamantina (1875-1890)

\begin{tabular}{|c|c|c|}
\hline N. de arrendamentos/titular & N. de ocorrências & \% do total da amostra \\
\hline 1 & 188 & 74,6 \\
\hline 2 ou 3 & 58 & 23,0 \\
\hline 4 ou mais & 06 & 2,4 \\
\hline
\end{tabular}

Fonte: APM. FP-107, fls. 91-125.

Os números referentes à citada amostra indicam coisas importantes: a) os conhecidos garimpeiros, isto é, pequenos mineradores, constituíram a maioria dos agentes envolvidos com a economia do diamante no período em tela; b) embora houvesse mineradores titulares de muitas e grandes áreas, eles representaram fatia diminuta dos arrendatários registrados na Administração. O fato é que, embora os garimpeiros respondessem pelo maior número de arrendamentos, eles não produziram a maior quantidade de diamantes.

\section{A atuação da Repartição dos Terrenos Diamantinos: acomodações, tensões e conflitos}

Como se saiu a Administração Geral dos Terrenos Diamantinos em suas funções de gestão, controle e fiscalização?

A resposta deve começar pela análise da estrutura do órgão e sua dotação de recursos. Conforme o Livro de Matrícula dos Empregados da Administração Geral dos Terrenos Diamantinos, a repartição tinha sede em Diamantina e delegacias no Serro, Grão-Mogol, Conceição do Serro (atual Conceição do Mato Dentro), São Romão, Bagagem (atual Estrela do Sul, 
no Triângulo Mineiro) e Uberaba. ${ }^{49}$ Na sede, ficavam lotados os ocupantes dos cargos de inspetor geral, substituto do inspetor geral, procurador fiscal, substituto do procurador fiscal, secretário, engenheiro e porteiro. Nas delegacias, existiam os cargos de delegado do inspetor geral, ${ }^{50}$ substituto do delegado (sempre vago, exceto no Serro), agente do procurador fiscal e substituto do agente (também sempre vago, exceto no Serro). Na Delegacia do Serro, havia ainda o cargo de prático, um auxiliar do engenheiro nos trabalhos de medição e demarcação dos lotes diamantinos.

De imediato, vê-se que o pessoal da Administração era exíguo para o desempenho eficaz das missões que lhes eram atribuídas. Quadro que se agrava em função das distâncias entre as cidades e a imensidão das áreas que deviam ser cobertas, num cenário provincial de populações dispersas, estradas e comunicações precárias. Esta dificuldade é realçada em ofício do inspetor geral ao presidente da Província, conselheiro Vicente Pires da Mota, de 18 de maio de 1861, transcrito a seguir:

Tenho a honra de acusar a recepção da Portaria de V. Exc. datada de 6 de abril último, ordenando-me nela que informe sobre os terrenos diamantinos da Serra do Cabral e rio Jequitaí que pedi em ofício de 29 de janeiro pp para serem declarados tais. $1^{\circ}$ ) Qual a época do descobrimento dos diamantes. 2 Qual a extensão provável da área. $3^{\circ}$ ) Qual a sua população. $4^{\circ}$ ) Finalmente que quantidade de diamantes se teria ali extraído, e em resposta tomo a liberdade de dizer que, por enquanto, não me é possível cumprir minuciosamente as ordens de V. Exc. sem que obtenha para isso circunstanciados esclarecimentos de pessoas práticas dos lugares, visto que eles distam desta cidade 11 léguas pouco mais ou menos e ao presente pouco habitados pela razão dos motivos já ponderados em ofício de 10 do corrente mês que fiz subir a sua presença. Garanto porém a resposta da participação que V. Exc. se dignou fazer-me de ter pedido idênticas informações ao Delegado de Polícia do Termo de Passos acerca do descoberto diamantino nos terrenos adjacentes ao ribeirão das Canoas, fico inteirado e esperando as determinações de V. Exc. ${ }^{51}$

A forma encontrada pela Administração para contornar parcialmente o problema das distâncias foi recorrer às câmaras municipais. Por exemplo,

${ }^{49}$ APM. TD-05.

${ }^{50}$ Aos delegados nos municípios competia: fornecer informações circunstanciadas do estado dos terrenos diamantinos, elaborar relatório anual em que se descrevem os inconvenientes e defeitos observados para facilitar a fiscalização, e sugerir melhoramentos que a experiência lhes tivesse apontado em prol dos interesses da Fazenda.

${ }^{51}$ APM. TD-04, fls. 34v-35. Grifos nossos. 
em 11 de fevereiro de 1868, o inspetor geral solicitou ajuda aos vereadores de Santa Bárbara, no ofício transcrito a seguir:

À Câmara de Santa Bárbara. Constando-me que apareceram diamantes na Serra de Cocais ou suas imediações, a bem do serviço público, vou pedir-lhes as seguintes informações. Primeiro= a extensão diamantina contida nesse lugar. Segundo= qualidade e (?) dos diamantes. Terceiro= quantidade aproximada do extraído. Quarto= finalmente número de trabalhadores empregados nesse serviço. Esperando com brevidade que lhes for possível as informações que venho de pedir devo acrescentar que serei a VV. SS. muito agradecido pelo obséquio que espero merecer. (...) Presidente e mais vereadores da Câmara Municipal da Cidade de Santa Bárbara. ${ }^{52}$

Com este expediente, todavia, a Administração ficava à mercê da boa vontade das câmaras municipais, que não dispunham de muitos recursos e eram bastante suscetíveis às pressões dos seus munícipes, no sentido de deixar correr a boca pequena o aproveitamento de novos descobertos.

As tarefas da Administração eram embaraçadas também por problemas envolvendo os próprios funcionários. Um desses problemas era a interrupção frequente do expediente da Administração provocada pelas viagens do secretário. Afinal, era tarefa deste funcionário supervisionar, pessoalmente, os trabalhos de medição e demarcação dos lotes nas áreas de exploração diamantífera, preparar e acompanhar as hastas públicas nas diversas cidades onde havia delegacias da Administração. ${ }^{53}$ Por isso, ele permanecia dias fora de Diamantina e, então, a repartição praticamente ficava paralisada, causando o acúmulo de serviço. Para minorar esse problema, o inspetor geral sugeriu ao inspetor da Tesouraria da Fazenda, José João Ferreira de Souza Coutinho, em ofício de 31 de janeiro de 1861, que se autorizasse "chamar um jornaleiro que auxilie ao Secretário". ${ }^{54}$ A solicitação parece ter caído no vazio.

Outro problema era a morosidade dos processos internos da repartição, tanto em função de falhas dos funcionários quanto de espertezas, por assim dizer, dos mineradores. No primeiro caso, pode-se mencionar a demora das respostas das delegacias às solicitações da sede da Administração. Exemplo disso é fornecido pelo ofício de 11 de abril de 1861, enviado ao inspetor da Tesouraria da Fazenda, no qual o inspetor geral justifica-se diante da impos-

\footnotetext{
52 APM. TD-04, fl. 41. Ofício nos mesmos termos, e de mesma data, foi enviado à Câmara Municipal de Campanha, pedindo notícias sobre descobertos no rio Verde (freguesia de Mutuca), também na fl. 41.

53 Exigência presente no artigo 21 do regulamento de 17 de agosto de 1846.

${ }^{54}$ APM. TD-04, fls. 20-20v.
} 
sibilidade de entregar o relatório sobre movimento e arrecadação dos terrenos diamantinos, dizendo: "porque ainda não recebi das diversas delegacias desta Província as informações que já solicitei [o que] dificulta extraordinariamente os precisos dados para esse trabalho de tanta importância". ${ }^{55}$ Outro exemplo encontra-se no ofício enviado a Antônio Hermógenes Pereira Rosa, inspetor geral da Tesouraria da Fazenda, em 11 de março de 1886, solicitando a demissão do delegado de Conceição do Serro, nos seguintes termos:

Não tendo o atual Delegado dos terrenos diamantinos no município da Conceição dado a menor solução a ofícios que lhe dirigi, pedindo informações do estado daquela Delegacia, e tendo chegado a meu conhecimento diversas queixas contra o mesmo, quanto à falta de cumprimento de deveres, venho propor a sua demissão daquele cargo, e apresentar o nome do cidadão José Cândido da Costa Fonseca para substituí-lo, e a do cidadão Orozimbo de Paula e Silva para o de Agente do procurador Fiscal no mesmo município. ${ }^{56}$

O expediente do órgão ficava frequentemente paralisado pelo efeito das estratégias utilizadas pelos mineradores e seus advogados ou procuradores. Eram manobras que, explorando brechas da lei ou zonas cinzentas criadas pelos regulamentos, tinham o objetivo de arrastar os processos, evitando que chegassem a termo, quando isto convinha aos interesses dos mineradores. Exemplo desses estratagemas era a retenção de processos pelos advogados ou procuradores, de que se queixa o inspetor geral da Administração no ofício de 23 de março de 1886, enviado ao presidente da Província. Apesar de longo, vale transcrever esse documento:

(...) Verá V. Exc. que com relação a matéria de recursos permitidos pelo Regulamento dado com o Decreto n. 5955 de 23 de junho de 1875, tem-se introduzido uma prática abusiva e prejudicial aos interesses das partes e da Fazenda Pública, que convém coibirse, é ela: que depois de interpostos os recursos pedem os recorrentes vista dos mesmos para razões; o Regulamento não marca prazo para tal vista, nem fala nela. Ficam os Advogados ou Procuradores com os autos por tempo que lhes apraz; em muitos casos este proceder só importa em um ganho de causa, como nos casos em que o recurso tenha efeito suspensivo. $\mathrm{O}$ regulamento em seus artigos 75 a 79 não autoriza semelhante vista que os advogados do cível querem transplantar para o processo destes recursos, mais administrativos e sumários do que os recursos do cível. Da leitura das disposições do Capítulo X do citado Regulamento convenço-me de que: a mesma petição que interpõe o recurso voluntário no prazo de 15 dias da intimação da decisão de que se

55 APM. TD-04, fl. 29v.

${ }^{56}$ APM. TD-04, fl. 52v. 
quer recorrer, deve trazer em si as razões ou fundamentos do recurso, sobre as quais informa o Inspetor, sem mais vista ao recorrente. É esta a forma geral de recursos no administrativo, e que me parece foi adaptada pelo Regulamento; entretanto, consulto V. Exc. se devo pô-la em prática, ou se tolerar a praxe até agora seguida e introduzida, talvez, pelos Advogados, e neste caso, qual meio de que se lançará mão a fim de evitar o abuso de ficarem os mesmos Advogados ou Procuradores com os recursos a título de arrazoá-los, indefinidamente. ${ }^{57}$

Vê-se que os mineradores souberam usar chicanas jurídicas para suspender ou torcer a seu favor decisões da Administração. Os mineradores de maiores recursos e também os faiscadores souberam assimilar os procedimentos e ritos da repartição em proveito próprio. Obrigados pela legislação a tirar licenças individuais anualmente para trabalhar, pagando selo e direito correspondente, os faiscadores conseguiram impor à Secretaria da Administração Diamantina a prática de retirar "uma só carta para três, dez e mais indivíduos debaixo de um só selo"..$^{58}$ Em contrapartida, cada faiscador satisfazia a obrigação de pagar dois mil réis anuais da taxa correspondente às licenças. Tal arranjo representou uma "acomodação" da legislação, aceita pela própria repartição encarregada de aplicá-la, diante das condições reais da região e dos trabalhadores da mineração. Acomodação que atendia interesses de ambas as partes e, por isso mesmo, contribuía para legitimar, em medida não desprezível, a convivência dessas mesmas partes.

Estes exemplos reforçam a linha interpretativa de autores que, ao abordar as relações Estado-sociedade no período monárquico, realçam a existência de estratégias populares diversificadas, forjadas na vivência cotidiana e em resposta a demandas específicas, que foram capazes de implementar, em alguma medida, interesses das gentes mais simples por meio do recurso a determinadas instituições estatais e a lei. Assim, as relações Estado-sociedade não foram dadas apenas pelos diplomas legais, mas construídas na interação de experiências de grupos diversos que procuravam fazer valer seus direitos. ${ }^{59}$

Aliás, uma forma curiosa de ludibriar a legislação minerária e fazer de boba a Administração era, simplesmente, não comunicar a morte dos titulares de termos de contrato, o que muitos herdeiros fizeram. Tal "jeitinho" foi denunciado pelo inspetor geral no seguinte ofício:

\footnotetext{
57 APM. TD-04, fls. 53-53v.

${ }^{58}$ Ofício de 27 de abril de 1861, enviado ao inspetor da Tesouraria da Fazenda. APM. TD-04, fls. 31-31v.

${ }^{59}$ Ver, por exemplo, RIBEIRO, Gladys Sabina (org.). Brasileiros e cidadãos. São Paulo: Alameda, 2008.
} 
Ao Coletor Geral, Sr. Antônio Pedro de Oliveira Catta Preta, 10 de junho de 1868. Denuncio a prática de que herdeiros de arrendatários já falecidos continuam fazendo pagamentos anuais na Coletoria do Município, fugindo à exigência legal de habilitação perante a Administração, atentando contra os interesses da Fazenda e o cumprimento da Lei. A Administração roga que não sejam mais fornecidos os talões, para boa ordem da Administração. ${ }^{60}$

Mais do que caso folclórico, o ofício acima revela certa confusão administrativa, pois órgãos governamentais distintos, que deveriam agir articuladamente, se limitavam a perseguir estritamente suas finalidades, gerando choques ou dificuldades para a atuação dos outros. Deve-se também mencionar a insistente desconfiança que a Administração nutria em relação à Polícia. O ofício de 27 de janeiro de 1861, enviado ao presidente da Província, conselheiro Vicente Pires da Motta, é esclarecedor a este respeito. Lê-se no referido documento:

Acontecendo que se suscitem questões tão desagradáveis entre os mineiros da extração diamantina a ponto de se tornarem tumultuárias, casos estes que por várias vezes se tem reproduzido, e mesmo para que seja mais respeitada esta Administração, e haja uma restrita fiscalização, que melhor interesse resulte a Fazenda Geral, julgo de absoluta necessidade que esteja aqui o destacamento de que trata o art. $5^{\circ}$ do Regulamento de 17 de agosto de 1846, visto que o existente além de ser insuficiente em número para executar as ordens das Autoridades Policiais, é composto de Guardas Nacionais do lugar que se tornam suspeitos para as diligências desta Administração, rogo pois a V. Exc. que se digne atender ao que levo exposto se julgar que assim convém, embora seja o número incompleto do merecido no dito Regulamento. ${ }^{61}$

Ora, a necessidade da Administração Geral dos Terrenos Diamantinos de recorrer à Guarda Nacional de Diamantina constituía dificuldade real para o desempenho de suas funções. Afinal, muitos homens e os comandantes locais da Guarda Nacional eram mineradores, garimpeiros, familiares e amigos de mineradores, garimpeiros e faiscadores. Não estariam facilmente dispostos, portanto, a agir duramente contra os seus em nome da Administração.

A legislação minerária produzia dificuldades adicionais para a atuação da Administração. Cita-se aqui o caso da aplicação de impostos diferenciados de acordo com a natureza do terreno mineral. Em terrenos já explorados, os arrendatários deviam pagar menos do que os arrendatários situados em

\footnotetext{
${ }^{60}$ APM. TD-04, fl. 50v.
}

${ }^{61}$ APM. TD-04, fl. 20v. 
terrenos virgens. A questão é simples: na região de Diamantina, Serro e Grão Mogol, como determinar precisamente quais terrenos eram virgens e quais já tinham sido explorados? A tipificação dos terrenos resvalava para o campo da controvérsia. Situação patente no ofício de 18 de maio de 1861, enviado pelo inspetor geral para o presidente da Província, transcrito a seguir:

\footnotetext{
Recebido ontem um ofício do Delegado dos Terrenos Diamantinos do município do Serro trazendo junto do Engenheiro Prático ao mesmo dirigido e que tenho de passar às mãos de $\mathrm{V}$. Exc. incluso por cópia, rogo a V. Exc. se digne dizer-me se o terreno descoberto e que contem diamantes está nas circunstâncias de ser declarado diamantino como deseja saber o mesmo Delegado; porque eu vacilo na decisão afirmativa de se dever entender já conhecido diamantino o dito terreno visto não ter sido ainda explorado e estar por isso sujeito a imposição de cinco reais por braça quadrada porque o terreno ainda não foi lavrado como se depreende da declaração do mesmo Delegado, conquanto esteja dentro do Município; neste sentido responde aquele Delegado aguardando a deliberação de V. Exc. ${ }^{62}$
}

Como entender a divergência entre o delegado do Serro e o inspetor geral a respeito da tipificação do terreno mineral? O delegado do Serro, por causa da proximidade mais vulnerável às pressões dos mineradores locais (que prefeririam pagar o imposto menor), inclinava-se por declarar a área diamantina, isto é, conhecida e explorada. O inspetor geral, mais distante e talvez aferrado à letra da lei, preferia tipificar a área como virgem, alegando que nela não havia lavra. Quem tinha razão? O tom anedótico da situação fica por conta do apelo ao presidente da Província, que, de Ouro Preto, daria a palavra final sobre a "virgindade" do terreno situado no Serro.

No que concerne à fiscalização das áreas de lavra, a Administração Geral dos Terrenos Diamantinos realizava inspeções de campo e tentava responder prontamente às denúncias que chegava a conhecer. O mecanismo das inspeções fica explicitado ao se ler a portaria de 28 de janeiro de 1861, assinada pelo inspetor geral José Ferreira de Souza Coutinho, que determinava:

O Porteiro desta Administração se apresentará com a possível brevidade no Primeiro Distrito Diamantino, destinado aos faiscadores e exigirá dos mineiros ali empregados todas as licenças que houverem obtido desta Repartição para minerar, fazendo em vista delas uma relação circunstanciada com declaração dos nomes dos indivíduos que tiverem obtido as licenças, número dos trabalhadores marcados e as datas das

${ }^{62}$ APM. TD-04, fls. 33v-34. Grifo nosso. 
mesmas licenças, dando-me uma circunstanciada parte de tudo quanto encontrar para ser providenciado na forma prescrita nos Regulamentos em vigor. ${ }^{63}$

Inspeções deste tipo ocorriam nas áreas mais próximas da sede da Administração. Entretanto, praticamente não havia condições de estendê-las aos locais mais distantes de Diamantina. A fiscalização direta, realizada pela própria repartição, ficava comprometida. Por conseguinte, reativamente, a Administração passou a depender das denúncias para levar a termo sua tarefa fiscalizadora. Recebida a denúncia, a chefia da repartição acionava a autoridade que mais rapidamente pudesse cessar a irregularidade. Podia ser um delegado do inspetor geral ou um delegado de Polícia. Na invasão do lote contratado por dona Carolina Gabriela da Fonseca, a Secretaria da Administração oficiou, em 12 de março de 1886, o delegado dos Terrenos Diamantinos do Serro, informando-o do fato e dando-lhe as seguintes instruções:

(...) Cumpre a essa Delegacia mandar intimar os invasores a que se retirem tomando ao mesmo tempo uma relação dos que ali forem encontrados trabalhando a fim de serem multados e executados; e no caso de resistência ou reincidência deve a arrendatária requerer à autoridade judiciária instaurar o respectivo processo. É esta a praxe seguida em casos idênticos, a qual essa Delegacia deve seguir. ${ }^{64}$

Já na denúncia da presença de faiscadores em uma área de Diamantina, a Administração acionou o delegado de Polícia do Termo, tenente João Teodoro Fernandes, da seguinte forma:

31 de março de 1868. Denunciando perante V. S. o Capitão Antônio Mendes de Magalhães que no lugar denominado Mata dos Crioulos acha-se um grupo de pessoas minerando, sem título legítimo, os terrenos diamantinos situados em aquele lugar, a bem do serviço público e para que sejam respeitados os direitos da Fazenda Nacional requisito de V. S. os praças que julgar necessários a fim de, auxiliados pelo Porteiro desta repartição, irem ao lugar vedar este ato criminoso. ${ }^{65}$

Mas a questão crucial quando se discute a atuação da Administração Geral dos Terrenos Diamantinos é, sem dúvida, a de saber a quem ela servia prioritariamente: ao Estado e ao interesse público, aos interesses privados

${ }^{63}$ APM. TD-04, fl. 19v.

${ }^{64}$ APM. TD-04, fl. 52.

${ }^{65}$ APM. TD-04, fl. 43. O capitão Antônio Mendes de Magalhães era conhecido fazendeiro na mata dos Crioulos. Sua denúncia talvez fosse motivada pela impossibilidade de exigir de mineradores ilegais qualquer percentual sobre os diamantes extraídos. 
dos grandes mineradores e diamantários, ou aos garimpeiros e faiscadores? Trata-se de identificar a presença recorrente de algum tipo de viés no desempenho da repartição, de saber se ela foi ou não firmemente capturada por certos grupos e, por isso, transformada em instrumento de promoção de determinados interesses. ${ }^{66}$

Entre os memorialistas de Diamantina, predomina a ideia de que a Administração cumpriu papel importante e positivo na região, não apenas porque teria conseguido organizar as áreas de lavra, mas porque teria estimulado a economia do diamante ao apoiar as sociedades mineradoras e, na virada para o século XX, as companhias estrangeiras e nacionais que entraram na região. ${ }^{67}$ Segundo Soter Ramos Couto, nos tempos da Administração Geral dos Terrenos Diamantinos, a mineração "não estava presa a firma ou pessoa, mas nas mãos de milhares de indivíduos e era mais bem repartida, fazendo a felicidade de centenas de lares". ${ }^{68}$

Visão bem diferente encontra-se na memória de garimpeiros. Depoimentos de antigos garimpeiros, recolhidos na década de 1990, contêm muitas histórias, contadas de geração a geração, que afirmam o conluio de interesses entre a Administração e os grandes mineradores, enfatizando a perseguição contra garimpeiros e faiscadores com o objetivo de expulsá-los de ricas terras minerais. ${ }^{69}$ Quem está com a razão: os memorialistas ou a tradição oral garimpeira?

O exame da lista de ocupantes dos principais postos da Administração Geral dos Terrenos Diamantinos mostra que ela sempre esteve muito próxima dos grandes mineradores e comerciantes de pedras. Homens estreitamente vinculados aos negócios de diamante exerceram os cargos de inspetor geral, substituto do inspetor, procurador fiscal, substituto do procurador, delegado e agente do procurador fiscal (ver anexo 2): em Diamantina, pes-

\footnotetext{
${ }^{66}$ Há longa tradição de análise que afirma a baixa capacidade operativa do governo imperial, no sentido de que o governo teria tido muito baixa presença efetiva no âmbito local. Assim, a maior parte do país viveria como se não existisse governo, porque as funções de governo seriam exercidas por agentes privados, configurando um quadro de fragmentação política real. Ver LESSA, Renato. Aventuras do barão de Munchausen: notas sobre a tradição presidencialista brasileira. In: LANZARO, Jorge (org.). Tipos de presidencialismo y coaliciones politicas em America Latina. Buenos Aires: Clacso, 2001. SCHWARTZMAN, Simon. A invenção republicana. Rio de Janeiro: Topbooks, 1999; Idem. São Paulo e o Estado nacional. São Paulo: Difel, 1975.

${ }^{67}$ ARNO, Ciro. Memórias de um estudante, 1885-1906. 2. ed. Rio de Janeiro: Gráfica Olímpica, 1949. COUTO, Soter. Vultos e fatos de Diamantina. 2. ed. Belo Horizonte: Armazém de Ideias, 2002.

${ }^{68}$ COUTO, Soter. Vultos e fatos de Diamantina, 2002, op. cit., p. 241.

${ }^{69}$ Ver MARTINS, Marcos Lobato. Identidades sociais e ação coletiva, 1977, op. cit., cap. 2.
} 
soas das famílias Caldeira, Andrade Brant, Alves Ferreira, Fernandes, Araújo Tameirão e Mourão, nas quais abundavam mineradores, diamantários e chefes políticos locais; no Serro, nomes como Ferreira Rabello, Ávila e Silva, Caldeira e Almeida e Silva, tradicionalmente dedicados à política, mineração e comércio. ${ }^{70}$

Vale ressaltar que a praxe da Administração era a de solicitar às câmaras municipais das cidades onde havia Delegacia dos Terrenos Diamantinos indicações de nomes para preencher os postos locais. Isto fica evidente no ofício de 30 de janeiro de 1868, enviado à Câmara de Uberaba, no qual se lê:

Tendo sido declaradas diamantinas as terras do Município de Uberaba pelo Aviso do Ministério da Fazenda de 31 de janeiro de 1853 e bem assim nomeado para servir de Delegado da Administração Geral dos Terrenos Diamantinos o cidadão João Quitério Teixeira, por Portaria de 10 de fevereiro do dito ano e não constando nesta Repartição mais nada a tal respeito, é do meu dever restabelecer a ordem e efetividade do cumprimento da Lei e por isso vou rogas a VV. SS., a bem do serviço público para dignarem-se prestar-me as seguintes informações. (...) Quinta= pessoas idôneas que possam com dignidade exercer os empregos de Delegado da Inspetoria e seu Substituto, de Agente do Procurador Fiscal e seu Substituto e finalmente para Prático medidor dos terrenos (..... ${ }^{71}$

As câmaras municipais, redutos das elites locais, indicavam nomes a elas afinados para ocupar os cargos da Administração. No caso da sede, em Diamantina, os políticos, os grandes mineradores e os diamantários da cidade tomaram como questão de honra (e de sobrevivência) influir sobre as nomeações, mesmo porque a mineração era a principal indústria da região e o município, o mais destacado produtor de diamantes do país.

Também é verdade que a Administração Geral dos Terrenos Diamantinos favoreceu e apoiou a formação de sociedades de grandes mineradores para explorar áreas ricas em diamantes, principalmente os novos descobertos. A repartição jogou seu peso no encaminhamento de propostas dessas sociedades para o governo provincial e o Ministério da Fazenda. Veja-se, por exemplo, o ofício de Roberto Alves Ferreira Taioba, substituto do inspetor geral em exercício, dirigido ao inspetor da Tesouraria, em 13 de agosto de 1856:

\footnotetext{
${ }^{70}$ Para informações sobre a posição de algumas destas famílias, ver o almanaque escrito por MARTINS, Antônio de Assis. Almanak administrativo, civil e industrial da Província de Minas Gerais do ano de 1869. Rio de Janeiro: Typographia do Diário do Rio de Janeiro, 1870, p. 201 e ss.

${ }^{71}$ APM. TD-04, fls. 39-39v.
} 
Remeto a V. S. para que submeta a aprovação do Exmo. Governo Imperial o contrato para arrendamento que acabo de celebrar com a companhia composta dos cidadãos Felisberto Ferreira Brant, Antônio Francisco dos Santos Fonseca, José Ferreira de Andrade Brant, Felisberto Ferreira Brant Jr., Augusto Ferreira Brant, Luis José Queiroga, José Ferreira Brant e Cândido dos Santos Fonseca para minerarem no Rio Preto que atravessa a estrada para Curimataí, tendo de permanecerem da ponte que existe na referida estrada para baixo. ${ }^{72}$

Favorecimento igual recebeu a companhia composta pelos cidadãos Felisberto Caldeira Brant, barão de Araçuaí (um dos cicerones da estada de Tschudi em Diamantina), Luiz Antônio Homem, Francisco Gomes Ribeiro, Antônio Francisco dos Santos Fonseca, Juscelino Joaquim de Menezes, Francisco Antônio Pimenta e Eduardo Soares Pereira da Silva, para minerar nas cabeceiras do rio Preto. ${ }^{73}$ Outro exemplo de companhia de grandes mineradores favorecida pela Administração foi a que se formou, em Diamantina, para minerar no rio Jequitaí, em área de uma légua em quadro (9 milhões de braças quadradas), sob a obrigação de empregar cem trabalhadores e de pagar $3 \$ 000$ anuais por cada trabalhador, além de impedir a presença de faiscadores ${ }^{74}$ Essa companhia era integrada, entre outros, por Francisco José de Andrade e Silva, Rodrigo de Souza Reis (um dos citados guias de Tschudi em Diamantina), Diniz Tameirão Pinto e João da Mata Machado (pai do conselheiro e ex-ministro João da Mata Machado Filho). ${ }^{75}$

Os exemplos anteriores são suficientes para mostrar que a Administração preferiu, quando possível, destinar áreas ricas em diamantes para as companhias de mineração ao invés dos garimpeiros, opção que tem a ver com a influência dos grandes mineradores diamantinenses sobre a repartição, mas também com a crença de que tal escolha seria melhor para a produção e, portanto, para a Fazenda e o país. O que não significa que a Administração se curvasse, dócil e imediatamente, o tempo todo, aos desejos dos mineradores.

\footnotetext{
${ }^{72}$ APM. TD-04, fl. 7v.

73 Ofício de 10 de agosto de 1856, enviado à Tesouraria da Fazenda. APM. TD-04, fls 7v-8.

${ }^{74}$ Ofício para a Tesouraria da Fazenda, 13 de setembro de 1856. APM. TD-04, fls. 9v-10.

${ }^{75}$ Os contratos celebrados com ambas as companhias foram feitos pelo mesmo Roberto Alves Ferreira Taioba, substituto do inspetor geral em exercício. Este cidadão diamantinense foi minerador e participou de sociedades diversas, das quais participaram nomes como Felisberto Ferreira Brant, João da Mata Machado e José Ferreira de Andrade Brant. Conforme MARTINS, Marcos Lobato. Os negócios do diamante e os homens de fortuna na praça de Diamantina ..., 2004, op. cit., cap. 3.
} 
Em várias ocasiões, nos meados do século XIX, a repartição contrariou interesses dos mais poderosos agentes da economia do diamante na antiga Demarcação Diamantina. Fez isso, por exemplo, ao obstar ações de delegados de terrenos diamantinos que geravam favorecimentos a mineradores e ao impedir a exploração mineral de certas áreas, por temer prejuízos para populações próximas. Citam-se aqui somente dois casos ilustrativos.

Em 10 de novembro de 1857, o inspetor geral Francisco de Paula Meireles expediu portaria para a Delegacia do Serro, referente à demarcação do rio das Pedras. Por meio desse instrumento, o inspetor geral mandava ao delegado do Serro que não mais aceitasse requerimentos de concessão de lotes minerais no ribeirão dos Borbas e outros confluentes do rio das Pedras, tal como ele vinha fazendo, porque estas áreas, embora dentro de sua jurisdição, não eram designadas claramente pelo governo como terrenos diamantinos, apenas as do rio das Pedras. Além de cessar as concessões, o inspetor geral ordenava que a Delegacia do Serro enviasse para a sede da repartição cópia de todos os contratos que foram feitos no Serro, para verificar eventuais irregularidades. ${ }^{76}$ Sem dúvida, esta decisão da Administração embaraçava a exploração das ricas lavras existentes nos confluentes do rio das Pedras, tão cobiçadas pelos grandes mineradores e garimpeiros do município do Serro.

No ano de 1861, para preservar o abastecimento de água de Diamantina, a Administração impediu a exploração de diamantes no Guinda. O inspetor geral, em ofício de 16 de abril, enviado a João Pires Cardoso, ponderou:

Tendo o cidadão Francisco Gonçalves Ferreira requerido para serem levados a hasta pública 6000 braças quadradas de terrenos diamantinos que se acham devolutos nos Campos do Guinda, na ponta da serra denominada Lapa dos Couveiros, estrada acima até a altura que fica defronte da casa de Francisco Alves de Lima, embaracei que fosse o seu requerimento levado a praça, temendo que havendo-se o dito terreno fosse prejudicada a água que se presta a servidão pública desta cidade, pelo que deliberei convidar a V. S. e aos cidadãos Joaquim Cassemiro Lages e Dinis Tameirão Pinto, a fim de que, a bem do serviço público, se dignem a ir ao lugar examinar o mencionado terreno e daremseu parecer de comum acordo sobre o que julgar mais conveniente. Espero já tanto ao zelo e patriotismo de V. S. que não se negará a um trabalho de tanta transcendência. ${ }^{77}$

\footnotetext{
${ }^{76}$ APM. TD-04, fls. 15v-16.

77 APM. TD-04, fl. 31. De posse de parecer da comissão contrário ao pedido de exploração dos campos do Guinda, a Administração não atendeu ao minerador Francisco Gonçalves Ferreira. Sobre o episódio, diz a tradição oral diamantinense que muitos mineradores ficaram furiosos e passaram a insuflar faiscadores e garimpeiros no sentido de ocupar a área. Em 1873, uma multidão de faiscadores invadiu o Pau de Fruta, nos campos do Guinda, e abriu catas. A Ad-
} 
Os dois casos anteriores operam no sentido de exigir a relativização do ponto de vista que, focado no conceito de patrimonialismo e levando ao paroxismo a clássica interpretação de Raymundo Faoro, ${ }^{78}$ assegura ter sido completa a captura da máquina estatal pelos interesses dos segmentos mais abastados e poderosos das elites, nos tempos do Império. Sem essa relativização, não se poderá compreender porque inspetores gerais da Administração dos Terrenos Diamantinos propuseram mudar o tratamento conferido pela legislação minerária aos faiscadores, na direção de lhes oferecer mais áreas para lavrar e diminuir as suas obrigações.

Roberto Alves Ferreira Taioba, no relatório enviado à Tesouraria da Fazenda em 13 de setembro de 1856, elenca, entre as sugestões para melhorar a atuação da Administração dos Terrenos Diamantinos, o estado dos arrendatários e as rendas diamantinas, providências como: “(...) Que se amplie aos faiscadores a faculdade de trabalhar em todos os terrenos devolutos. (...) Que é melhor que se aceite o zelo dos serviços dos faiscadores que assim só tenham de pagar a taxa de que trata o art. $7^{\circ}$ do Decreto ou Resolução de 24 de setembro de 1845".79 Anos depois, José João Ferreira de Souza Coutinho, em ofício para a Tesouraria da Fazenda, datado de 8 de fevereiro de 1861, aduziu motivos similares para sugerir ao governo alguma modificação relativamente aos faiscadores, aos quais, na forma do art. 29 do regulamento de 17 de agosto de 1846, não era dada a faculdade de minerar em todos os lugares devolutos. Souza Coutinho pensava que a experiência indicava que "essa modificação será conveniente, não só como um meio mais fácil de fiscalização, mas ainda como medida policial de segurança e garantia dos terrenos nacionais", além de ter manifesta utilidade aos interesses da Fazenda. ${ }^{80} \mathrm{E}$ acrescentava: a modificação interessava à própria Administração, ou melhor, à sua imagem, uma vez que ela se livraria de enfrentar desafios de homens "que não se sujeitam a ação das autoridades, as quais não têm nem a força e nem o prestígio de podê-los conter nos limites de sua obediência, para fazer cumprir a Lei em lugares longínquos e despovoados". A linguagem de Souza Coutinho é a linguagem típica do magistrado, do funcionário de governo

ministração recorreu à Polícia e houve expulsão violenta dos invasores. Este acontecimento ficou conhecido como a "demanda do Pau de Fruta". Ver MARTINS, Marcos Lobato. Identidades sociais e ação coletiva ..., 1997, op. cit., cap. 2.

${ }^{78}$ FAORO, Raymundo. Os donos do poder: formação do patronato político brasileiro. 6. ed. Porto Alegre: Globo, 1984. 2v.

${ }^{79}$ APM. TD-04, fls. 8v-9.

${ }^{80}$ APM. TD-04, fls. 21-22v. 
que tem em alta conta as atribuições e qualidades precípuas do Estado: a força e respeitabilidade da lei, o controle do território nacional, o interesse da Fazenda, o prestígio das instituições, a eficácia da administração.

As preocupações de Roberto Taioba e de Souza Coutinho indicam certo grau de compromisso com a busca de racionalização da administração, da rotinização das ações de governo, o que tem a ver com aspectos de um processo, ainda que incipiente e mesmo lento, de consolidação do Estado e de formas modernas de gestão governamental, na direção da lógica burocrática. Também fica claro que inspetores gerais e procuradores fiscais da Administração Diamantina perceberam que o poder do Estado não poderia prescindir de espaços e margens de negociações, a fim de alcançar níveis abrangentes de controle da ordem e administrar eficazmente conflitos socioeconômicos, no interior das áreas de exploração diamantífera. A atuação da Administração Diamantina, nesse sentido, pode ser caracterizada como "uma contínua sondagem entre governantes e súditos, a fim de descobrir o que eles podem efetuar impunemente". ${ }^{81}$

Noutras palavras, a Administração Geral dos Terrenos Diamantinos operava como instância - tal como a Justiça - à qual recorriam homens livres pobres das camadas intermediárias e mesmo as elites locais, em maior ou menor grau, para tentar a solução de seus conflitos, demandando alguma ordem e previsibilidade para viver e trabalhar. ${ }^{82} \mathrm{O}$ que significa que, no processo de construção da ordem legal, do aparato institucional e da contenção da violência nas áreas de mineração ao redor de Diamantina, no período em tela, a repartição produziu bem mais do que "cascalho normativo formal". Na verdade, a Administração Geral dos Terrenos Diamantinos enfrentou com algum sucesso a complicada tarefa de encontrar caminho entre a ordem legal produzida pelo Estado e o direito consuetudinário das comunidades de garimpeiros e faiscadores.

\section{Considerações finais}

O exame da documentação da Administração Geral dos Terrenos Diamantinos fornece indícios que corroboram a visão de viajantes e de memorialistas que assinalaram o dinamismo da economia do diamante, em

\footnotetext{
${ }^{81}$ MOORE JR, Barrington. Injustiça: as bases sociais da obediência e da revolta. São Paulo: Brasiliense, 1987, p. 39. 82 VELLASCO, Ivan de Andrade. As seduções da ordem: violência, criminalidade e administração da justiça. Minas Gerais, século 19. Bauru, SP: Edusc, 2004.
} 
meados dos Oitocentos, nas terras da antiga Demarcação Diamantina. A atividade envolvia diretamente milhares de trabalhadores e gerava arrecadação anual expressiva de impostos.

A despeito das distâncias, do número escasso de funcionários e das ambiguidades da legislação do setor, a Administração Geral dos Terrenos Diamantinos alcançou razoável sucesso no desempenho de sua missão. Sua atuação, mais notada nas proximidades de Diamantina, integrou-se à vida ordinária dos mineradores, que se acostumaram às medições, demarcações e hastas públicas realizadas pela Administração, bem como ao combate que ela promoveu contra as invasões de lotes minerais e irregularidades nos arrendamentos e concessões. Grandes mineradores, garimpeiros e faiscadores aprenderam a lidar com a Administração Geral dos Terrenos Diamantinos e tentaram influir sobre suas decisões. Os grandes mineradores e comerciantes de diamante apossaram-se de muitos cargos na repartição e, com isso, obtiveram preferência nas concessões de novas áreas e apoio na formação de sociedades mineradoras. Contudo, a Administração Geral dos Terrenos Diamantinos não foi de todo insensível aos interesses de garimpeiros e faiscadores. Ajustando a legislação à realidade regional, permitiu aos faiscadores minerar em terras devolutas e adotou procedimentos que contribuíram para reduzir custos que pesavam sobre os pequenos mineradores.

Nesse sentido, é preciso abandonar o lugar comum historiográfico que insiste na caracterização do aparelho estatal presente em Minas Gerais como ineficiente, inoperante e, sobretudo, inacessível aos de "baixo". Ao contrário, o exame da atuação da Administração Geral dos Terrenos Diamantinos traz elementos que autorizam pensar esta instância governativa como campo privilegiado do processo de negociação da ordem, no qual atores sociais diversos buscaram o reconhecimento e a efetivação de seus direitos. 


\section{Anexo 1 - Grandes mineradores do município do Serro (1865-1869)}

\begin{tabular}{|c|c|c|c|}
\hline Local & Ano & Mineradores & $\begin{array}{l}\text { Imposto } \\
\text { (R\$) }\end{array}$ \\
\hline Córrego dos Ausentes & 1866 & Aureliano Augusto Leão & 56,6 mil \\
\hline Capivari & 1866 & Nicolau Teixeira de Araújo & $43 \mathrm{mil}$ \\
\hline Brogodões (rio do Peixe) & 1868 & $\begin{array}{l}\text { Joaquim Carlos de Abreu, Dr. José Joaquim } \\
\text { Ferreira Rabello, João José Simões, Henrique } \\
\text { Carlos de Vasconcellos Lessa, Modesto Correia } \\
\text { de Almeida e José Feliciano Correia da Almeida }\end{array}$ & 35 mil \\
\hline $\begin{array}{l}\text { Córrego Cadete (rio do } \\
\text { Peixe) }\end{array}$ & 1866 & Major José Ávila Bittencourt & $31,9 \mathrm{mil}$ \\
\hline Córrego Água Quente & 1868 & Firmiano Corrêa de Souza & $30 \mathrm{mil}$ \\
\hline Rio Capivari & 1868 & Joaquim Pereira de Assumpção & $30 \mathrm{mil}$ \\
\hline Córrego Duas Pontes & 1868 & $\begin{array}{l}\text { Joaquim Carlos de Abreu, dr. José Joaquim } \\
\text { Ferreira Rabello, dr. Bernardino José Pereira de } \\
\text { Queirós, Joaquim Antônio de Souza, Serafim } \\
\text { Alves Pinheiro }\end{array}$ & $30 \mathrm{mil}$ \\
\hline Brumado (Descoberto) & 1868 & Vigário Agostinho Francisco Paraíso & $30 \mathrm{mil}$ \\
\hline Córrego Bernardino & 1869 & Antônio Raimundo da Costa & $30 \mathrm{mil}$ \\
\hline $\begin{array}{l}\text { Córrego Riacho (Pedra } \\
\text { Redonda) }\end{array}$ & 1868 & $\begin{array}{l}\text { Luiz Ferreira dos Santos, Luciano Jorge de } \\
\text { Souza }\end{array}$ & $30 \mathrm{mil}$ \\
\hline $\begin{array}{l}\text { Córrego Santana (Pedra } \\
\text { Redonda) }\end{array}$ & 1868 & $\begin{array}{l}\text { Luiz Ferreira dos Santos, Luciano Jorge de } \\
\text { Souza }\end{array}$ & $30 \mathrm{mil}$ \\
\hline Córrego Malheiro & 1868 & Pedro Vieira Pinto & $30 \mathrm{mil}$ \\
\hline Córrego São João & 1869 & $\begin{array}{l}\text { Joaquim Rodrigues de Loyola (confluente rio } \\
\text { do Peixe) }\end{array}$ & $30 \mathrm{mil}$ \\
\hline Córrego Pai Félix & 1869 & $\begin{array}{l}\text { Francisco de Paula Araújo (confluente do } \\
\text { Capivari) }\end{array}$ & $30 \mathrm{mil}$ \\
\hline Córrego Gales & 1869 & José Libânio Horta & $30 \mathrm{mil}$ \\
\hline Massangano & 1866 & João Jacomeny & $30 \mathrm{mil}$ \\
\hline Rio do Peixe & 1867 & Pedro Generoso de Almeida e Silva & $30 \mathrm{mil}$ \\
\hline Córrego Retiro (Cafundós) & 1864 & José Ferreira & $30 \mathrm{mil}$ \\
\hline Córrego Sumidouro & 1868 & Manuel Francisco Lopes (Pedra Redonda) & 30 mil \\
\hline Capivari Pequeno & 1868 & Serafim Ribeiro Caldas & $30 \mathrm{mil}$ \\
\hline Córrego Prata Grande & 1868 & José Pedro Lessa & $30 \mathrm{mil}$ \\
\hline $\begin{array}{l}\text { Córrego Retiro e Ribeirão } \\
\text { São Bartolomeu }\end{array}$ & 1869 & José Pedro Lessa & $30 \mathrm{mil}$ \\
\hline Córrego Mandiocal & 1868 & $\begin{array}{l}\text { Paulo Fernando Leão, Pedro Barreto Lima, Tor- } \\
\text { guato Pinheiro Neves }\end{array}$ & $30 \mathrm{mil}$ \\
\hline Córrego São Gonçalo & 1865 & Capitão João Raimundo Mourão & $20 \mathrm{mil}$ \\
\hline Rio do Peixe & 1866 & Dario Clementino da Silva & $20 \mathrm{mil}$ \\
\hline Acabasaco & 1866 & Francisco José de Souza & 20 mil \\
\hline Córrego São Gonçalo & 1867 & Francisca Tereza d'Aguiar Souza & $20 \mathrm{mil}$ \\
\hline Rio do Peixe & 1867 & Dr. José Joaquim Ferreira Rabello & $19 \mathrm{mil}$ \\
\hline Rio do Peixe (Caeté) & 1866 & Francisco José Simões & $20 \mathrm{mil}$ \\
\hline
\end{tabular}

Fonte: Livro de Termos de Contrato e Arrendamento de Lotes (Serro, 1865-69). TD-08. APM. 


\section{Anexo 2 - Ocupantes de cargos da Administração Diamantina (1860-1889)}

\begin{tabular}{|c|c|}
\hline Cargos na sede da Adminstração (Diamantina) & Período \\
\hline \multicolumn{2}{|l|}{ Inspetor geral } \\
\hline $\begin{array}{l}\text { Nicolau Antônio Tassara de Pádua } \\
\text { Vicente José de Figueiredo } \\
\text { João Evangelista Caldeira } \\
\text { José Ferreira de Andrade Brant } \\
\text { João Evangelista Caldeira }\end{array}$ & $\begin{array}{c}1860-1871 \\
1871-1878 \\
1878-1883 \\
1883-1889 \\
1889\end{array}$ \\
\hline \multicolumn{2}{|l|}{ Substituto do inspetor geral } \\
\hline $\begin{array}{l}\text { Major Roberto Alves Ferreira Taioba } \\
\text { Manoel Ricardo Pires Camargo } \\
\text { Ragosino Alves Ferreira }\end{array}$ & $\begin{array}{l}1860-1871 \\
1884 \\
1885\end{array}$ \\
\hline \multicolumn{2}{|l|}{ Procurador fiscal } \\
\hline $\begin{array}{l}\text { Manoel Severo Pires de Figueiredo Neto } \\
\text { Advogado João Raimundo Mourão } \\
\text { João Sebastião Roiz Bago } \\
\text { Francisco Diogo de Araújo Tameirão } \\
\text { Major Henrique José Afonso Fernandes }\end{array}$ & $\begin{array}{c}\text { Até } 1878 \\
1878-1880 \\
1880-1882 \\
1882-1885 \\
1885-1887\end{array}$ \\
\hline \multicolumn{2}{|l|}{ Substituto do procurador fiscal } \\
\hline $\begin{array}{l}\text { Advogado Clementino Rabello de Campos } \\
\text { Advogado João Raimundo Mourão } \\
\text { Bernardino da Cunha Ferreira }\end{array}$ & $\begin{array}{l}1876 \\
1884 \\
1886\end{array}$ \\
\hline \multicolumn{2}{|l|}{ Secretário } \\
\hline $\begin{array}{l}\text { Elizeu Augusto de Assis Jardim } \\
\text { Justiniano Luiz de Miranda Jr. } \\
\text { João Batista de Mello Brandão } \\
\text { Justiniano Luiz de Miranda Jr. }\end{array}$ & $\begin{array}{c}1860-1882 \\
1882-1885 \\
1885-1889 \\
1889\end{array}$ \\
\hline \multicolumn{2}{|l|}{ Engenheiro } \\
\hline $\begin{array}{l}\text { Antônio Joaquim da Fonseca } \\
\text { Francisco de Paula e Sousa Matos } \\
\text { Joaquim Gonçalves Pimentel } \\
\text { Tenente Antônio Joaquim da Fonseca } \\
\text { Antônio Getúlio dos Santos }\end{array}$ & $\begin{array}{c}1875-1878 \\
1878-1882 \\
1882-1885 \\
1885-1889 \\
1889\end{array}$ \\
\hline \multicolumn{2}{|l|}{ Porteiro } \\
\hline Possidônio da Costa & 1871-1889 \\
\hline
\end{tabular}


continuação do Anexo 2

\begin{tabular}{|c|c|}
\hline Cargos na Delegacia do Serro & Período \\
\hline \multicolumn{2}{|c|}{ Delegado do inspetor geral } \\
\hline $\begin{array}{l}\text { Clarindo Ferreira Campos } \\
\text { Advogado Antônio Caetano de Ávila e Silva } \\
\text { Ângelo Martins Caldeira }\end{array}$ & $\begin{array}{l}1871-1878 \\
1873-1887 \\
1887-1889\end{array}$ \\
\hline \multicolumn{2}{|c|}{ Substituto do delegado } \\
\hline $\begin{array}{l}\text { Bento Ferreira Carneiro } \\
\text { Antônio Cassemiro de Ávila } \\
\text { Teodoro Generoso de Almeida e Silva }\end{array}$ & $\begin{array}{c}1871 \\
1883-1886 \\
1886\end{array}$ \\
\hline \multicolumn{2}{|c|}{ Agente do procurador fiscal } \\
\hline $\begin{array}{l}\text { Joaquim de Cássia e Souza } \\
\text { Pedro da Cunha Ferreira Rabello } \\
\text { Carlos Henrique de Siqueira Ayala } \\
\text { Pedro da Cunha Ferreira Rabello }\end{array}$ & $\begin{array}{c}1871 \\
1881 \\
1883-1885 \\
1885\end{array}$ \\
\hline
\end{tabular}

Fonte: Matrícula dos empregados da Administração Geral dos Terrenos Diamantinos. TD-05. APM.

\section{Referências bibliográficas}

Fontes manuscritas

Arquivo Público Mineiro. Livro de Registro de lotes arrendados e dos arrendatários no município de Diamantina, 1875-1890. FP-107.

Arquivo Público Mineiro. Livro de Registro dos Ofícios expedidos pela Administração Diamantina, 1855-1886. TD-04.

Arquivo Público Mineiro. Livro de Matrícula dos empregados da Administração Geral dos Terrenos Diamantinos. TD-05.

Arquivo Público Mineiro. Livro de Matrícula dos lotes arrendados. Administração Geral dos Terrenos Diamantinos, 1861-1867. TD-06.

Arquivo Público Mineiro. Livro de Registros da Delegacia de Administração dos Terrenos Diamantinos do Serro, 1869-1908. TD-10. 
REVISTA DE HISTÓRIA

SÃO PAULO, N 167, p. 129-163,

JULHO / DEZEMBRO 2012
MARCOS LOBATO MARTINS

A mineração de diamantes e a administração geral dos terrenos diamantinos: Minas Gerais, décadas de 1830-1870

Fontes impressas

MARTINS, Antônio de Assis. Almanak administrativo, civil e industrial da Província de Minas Gerais do ano de 1869 para servir no de 1870, organizado e redigido em virtude da Lei Provincial n. 1447 do $1^{\circ}$ de janeiro de 1868. Rio de Janeiro: Typographia do Diário do Rio de Janeiro, 1870.

TSCHUDI, Johann Jakob von. Viagens através da América do Sul. Belo Horizonte: Fundação João Pinheiro, 2006. 2v.

Bibliografia

ARNO, Ciro. Memórias de um estudante, 1885-1906. 2. ed. Rio de Janeiro: Gráfica Olímpica, 1949.

BURTON, Richard F. Viagem de canoa de Sabará ao oceano Atlântico. Trad. David Jardim Junior. Belo Horizonte: Itatiaia; São Paulo: Edusp, 1977.

CATHARINO, José Martins. Garimpo, garimpeiro, garimpagem. Rio de Janeiro: Philobiblion; Salvador: Fundação Econômica Miguel Calmon, 1986.

COUTO, Soter. Vultos e fatos de Diamantina. 2. ed. Belo Horizonte: Armazém de Ideias, 2002.

ESCHWEGE, Wilhelm L. von. Pluto Brasiliensis. Trad. Domício de Figueiredo Murta. Belo Horizonte: Itatiaia; São Paulo: Edusp, 1979.

FAORO, Raymundo. Os donos do poder: formação do patronato político brasileiro. 6. ed. Porto Alegre: Globo, 1984. 2v.

FERREIRA, Rodrigo de Almeida. O descaminho de diamantes - relações de poder e sociabilidade na demarcação diamantina no período dos contratos (1740-1771). Belo Horizonte: Fumarc; São Paulo: Letra \& Voz, 2009.

FURTADO, Júnia Ferreira. O Livro da Capa Verde: o regimento diamantino de 1771 e a vida no distrito diamantino no período da Real Extração. São Paulo: Annablume, 1996.

LEONCY, Léo Ferreira. O regime jurídico da mineração no Brasil. Belém: NAEA/UFPA, 1997. (Paper do Núcleo de Altos Estudos Amazônicos, 73).

LESSA, Renato. Aventuras do barão de Munchausen: notas sobre a tradição presidencialista brasileira. In: LANZARO, Jorge (org.). Tipos de presidencialismo y coaliciones politicas en America Latina. Buenos Aires: Clacso, 2001.

MARTINS, Marcos Lobato. A crise dos negócios do diamante e as respostas dos homens de fortuna no Alto Jequitinhonha, décadas de 1870-1890. Estudos Econômicos. São Paulo, v. 38, n. 3, 2008, p. 611-638.

Os negócios do diamante e os homens de fortuna na praça de Diamantina, MG: 1870-1930. Tese de doutorado, História, FFLCH, USP, 2004.

Identidades sociais e ação coletiva: o caso dos garimpeiros da microrregião de Diamantina. Dissertação de mestrado, Sociologia, FAFICH, UFMG, 1977.

MATTOS, Ilmar Rohloff de. O tempo de Saquarema. São Paulo: Hucitec, 1987.

MOORE JÚNIOR, Barrington. Injustiça: as bases sociais da obediência e da revolta. São Paulo: Brasiliense, 1987.

RIBEIRO, Gladys Sabina (org.). Brasileiros e cidadãos. São Paulo: Alameda, 2008.

SAINT-HILAIRE, Auguste de. Viagem pelo distrito dos diamantes e litoral do Brasil. Trad. Leonam de Azeredo Pena. Belo Horizonte: Itatiaia; São Paulo: Edusp, 1974. 
SANTOS, Joaquim Felício dos. Memórias do Distrito Diamantino. 5. ed. Petrópolis, RJ: Vozes; Brasília: INL, 1978.

SCHWARTZMAN, Simon. A invenção republicana. Rio de Janeiro: Topbooks, 1999. São Paulo e o Estado Nacional. São Paulo: Difel, 1975.

SCLIAR, Cláudio. Geopolítica das minas do Brasil. Rio de Janeiro: Revan, 1996.

SOUZA, José Moreira de. Cidade: momentos e processos. Serro e Diamantina na formação do norte mineiro no século XIX. São Paulo: Marco Zero, 1993.

VASCONCELOS, José Matos de. Direito administrativo. Rio de Janeiro: Imprensa Nacional, 1936.

VELLASCO, Ivan de Andrade. As seduções da ordem: violência, criminalidade e administração da justiça. Minas Gerais, século 19. Bauru, SP: Edusc, 2004. 